\title{
A NOÇÃO DE LIBERDADE EM DESCARTES: IMPLICAÇÕES DAS VERSÕES LATINA E FRANCESA
}

\author{
Naama Enéas da Silva Almeida ${ }^{\mathbf{1}}$; Wagner Teles de Oliveira ${ }^{2}$; \\ 1. Bolsista PROBIC/CNPq, Graduanda em Psicologia, Universidade Estadual de Feira de Santana, e-mail: \\ naama_eneas@hotmail.com \\ 2. Orientador, Departamento de Ciências Humanas e Filosofia, Universidade Estadual de Feira de Santana, e-mail: \\ woteles@gmail.com
}

PALAVRAS-CHAVE: uma; duas; três.

\section{INTRODUÇÃO}

Compreender os motivos pelos quais os seres humanos são levados a agir do modo pelo qual o fazem tem sido - e continua sendo - uma questão constantemente debatida pela Filosofia. Esse texto tem por propósito realizar uma investigação acerca da noção de liberdade humana segundo Descartes. Para tanto, pretende-se compreender como se articulam os conceitos de 'entendimento', 'vontade', 'livre-arbítrio' e 'Deus' no sistema filosófico do mencionado autor, especialmente na obra Meditações. Os objetivos consistem em esclarecer as concepções de entendimento, vontade, livre-arbítrio e Deus, explicitar os argumentos utilizados por Descartes que sustentam a noção de livrearbítrio e evidenciar as alterações presentes na tradução francesa da obra Meditações, defendendo a tese de Descartes haver produzido um novo texto, ampliando assim a sua anterior concepção de liberdade da versão em latim.

\section{MATERIAL E MÉTODOS OU METODOLOGIA (ou equivalente)}

Tendo em vista técnicas de exegese e de escrita de textos que caracterizam o trabalho em filosofia, a execução das atividades concernidas pelo plano de trabalho privilegiou o cotejo com as fontes primárias da pesquisa, sobretudo Meditações, sem se furtar à apreciação de fontes secundárias, textos de destacados comentadores, que se inscrevem na tradição de leitura da obra de Descartes, como é o caso de Michelle Beyssade. Desse modo, o trabalho de pesquisa consistiu em duas etapas: a primeira envolvendo a leitura de textos indispensáveis à pesquisa, que foram cuidadosamente fichados, e a segunda realizada através da escrita. Essas duas etapas vinculam-se intrinsecamente pela elaboração de texto monográfico que foi gradativamente apresentado nas reuniões de nosso Grupo de Estudo e Pesquisa, de modo a permitir a apreciação dos resultados parciais da pesquisa e debate das questões com as quais ela lida. A apresentação pública dos resultados da pesquisa, vale dizer, constitui um importante componente metodológico, permitindo-me debater sistematicamente os resultados da minha pesquisa, perfazendo assim as condições de elevação da qualidade do trabalho.

\section{RESULTADOS E/OU DISCUSSÃO (ou Análise e discussão dos resultados)}

A execução dessa pesquisa resultou na produção do artigo "A noção de liberdade em Descartes: implicações das versões latina e francesa". Durante a sua produção, objetivamos compreender as noções de 'entendimento', 'vontade' (ou liberdade), 'livre-arbítrio' e 'Deus' - apresentadas na obra Meditações. Durante a articulação desses conceitos, analisamos as versões em latim (1641) e francês (1647) da obra, especialmente o capítulo da quarta meditação, demonstrando as principais diferenças e variações terminológicas entre as traduções. Assim, apoiando-nos no artigo de Michelle Beyssade A doutrina da liberdade de Descartes: diferenças entre os textos francês e latino da quarta meditação, defendemos a tese de Descartes haver produzido 
um novo texto em 1647, no qual as alterações trazidas pelo filósofo atestam a ampliação ou evolução da sua anterior concepção de liberdade.

Sobre o modo pelo qual a liberdade opera nos homens, Descartes afirma que quanto mais claro e distinto um conteúdo é concebido pelo homem, mais irresistivelmente sua vontade (liberdade) inclinar-se-á sobre tal conteúdo. No entanto, por ser uma substância imperfeita, Descartes afirma não ser uma ocorrência admirável que ele cometa erros. O filósofo compreende o erro como um defeito decorrente da sua capacidade finita de discernir o verdadeiro do falso, da ausência de algum conhecimento que não possui. Devido à sua condição ontológica de substância intelectual finita, faltam-lhe muitas coisas e, consequentemente, diante da privação de algum conhecimento, ele é capaz de errar. Entretanto, Deus não poderia ser responsabilizado pela ocorrência dos seus erros, visto que as faculdades concedidas por Ele estão essencialmente ligadas à verdade. Os erros, então, provêm da liberdade de arbítrio, a qual extrapola os limites do que se pode conceber com clareza e distinção pelo entendimento, podendo desviar-se do verdadeiro e do bom e agir sobre conteúdos obscuros. Portanto, a ocorrência do erro seria decorrente da capacidade finita do entendimento aliada a capacidade infinita da vontade, e não consequência de outra faculdade concedida por Deus especificamente para essa finalidade.

No tocante as divergências entre as versões latina e francesa, compreendemos que conceito de liberdade apresentado no texto latino toma como não essencial ao exercício da liberdade a possibilidade de escolher entre o bem e o mal (poder dos contrários). O livre-arbítrio consistiria fundamentalmente num poder de escolha direcionado espontaneamente (pelo próprio entendimento ou por ação divina) a um dos lados possíveis: o lado da verdade. Já na versão francesa, é apresentada como não necessária ao exercício da liberdade a indiferença na escolha entre dois contrários, deixando em aberto a possibilidade de escolher ainda que tal decisão não esteja direcionada ao bom e verdadeiro.

\section{CONSIDERAÇÕES FINAIS (ou Conclusão)}

Diante da análise realizada entre os termos escolhidos por Descartes nas duas versões, inferimos que tanto a versão de 1641 quanto a de 1647 convergem quanto a essência da liberdade propriamente dita consistir no direcionamento espontâneo da vontade ao bom e verdadeiro, ou seja, na inclinação a priori irresistível aos conteúdos que são concebidos com clareza e distinção pelo entendimento. A diferença principal entre os dois textos, portanto, residiria na relação do exercício do livre-arbítrio com o poder dos contrários e estado da indiferença, sendo que esses últimos não fazem parte da perfeição da vontade no primeiro Descartes e, no segundo, passam a incorporá-la.

\section{REFERÊNCIAS}

Fontes primárias (obras de Descartes):

DESCARTES, René. Meditações sobre Filosofia Primeira. René Decartes; tradução: Fausto Castilho. Ed bilingue em latim e portugues - Campinas, SP: Editora da Unicamp, 2004.

. Meditações Metafísicas. São Paulo: Abril Cultura, 1973

Oeuvres de Descartes. Paris: Librairie Philosophique J. Vrin. 1996.

11 vol. Publiées par Charles Adam e Paul Tannery. . Princípios da Filosofia. São Paulo, Editora Rideel, 2005

Fontes secundárias: 
ALQUIÉ, Ferdinand. A filosofia de Descartes. $3^{\text {a }}$ edição, Lisboa, 1903.

BEYSSADE, Jean-Marie. Études sur Descartes. Paris: Éditions du Seuil, 2001.

BEYSSADE, Michelle. A doutrina da liberdade de Descartes: diferenças entre os textos francês e latino da quarta meditação. ANALYTICA, Rio de Janeiro, vol 13 nº 2, 2009, p.225242.

. Descartes. Tradução de João Gama. Lisboa: Edições 70, 1989.

ROCHA, Ethel Menezes. Infinitude da vontade nos homens e em Deus segundo Descartes. ANALYTICA, Rio de Janeiro, vol 15 nº 1, 2011, p.125-144.

SILVA, Franklin Leopoldo e. Descartes: a metafísica da modernidade. 2. Ed. São Paulo: Moderna, 2005. 